\title{
Landscape Works. Balancing Nature and Culture in the Pantelleria National Park
}

\author{
Romina D’Ascanio*(D), Lorenzo Barbieri, Giorgia De Pasquale $\mathbb{D}^{D}$, Andrea Filpa and Anna Laura Palazzo $\mathbb{D}$
}

check for updates

Citation: D'Ascanio, R.; Barbieri, L.; De Pasquale, G.; Filpa, A.; Palazzo, A.L. Landscape Works. Balancing Nature and Culture in the Pantelleria National Park. Sustainability 2021, 13, 13371. https://doi.org/10.3390/ su132313371

Academic Editor: Thomas A. Clark

Received: 30 September 2021

Accepted: 25 November 2021

Published: 2 December 2021

Publisher's Note: MDPI stays neutral with regard to jurisdictional claims in published maps and institutional affiliations.

Copyright: (c) 2021 by the authors. Licensee MDPI, Basel, Switzerland. This article is an open access article distributed under the terms and conditions of the Creative Commons Attribution (CC BY) license (https:// creativecommons.org/licenses/by/ $4.0 /)$.
Department of Architecture, Roma Tre University, 00153 Rome, Italy; lorenzo.barbieri@uniroma3.it (L.B.); giorgia.depasquale@uniroma3.it (G.D.P.); andrea.filpa@uniroma3.it (A.F.); annalaura.palazzo@uniroma3.it (A.L.P.)

* Correspondence: romina.dascanio@uniroma3.it
Abstract: Traditional agricultural practice and peculiar geographical features in the Mediterranean basin have not only moulded cultural and heritage values, but also created the conditions for the development of habitats to be protected. Therefore, Landscape proves a suitable concept both for the enhancement of cultural features and for nature conservation. The aim of this work is to apply the landscape approach to the Pantelleria National Park, providing the opportunity to reflect upon and discuss whether and how to encompass rural landscape planning and management within the broader context of natural values, offering a frame of reference for the zoning of the future Park Plan. Specifically, the research aims to define zoning categories, typical to protected areas planning, using criteria related to landscape features and patterns, environmental quality, traditional agriculture, architectural heritage. Established in 2016, the Pantelleria National Park is the most recent Italian National Park and the first one in Sicily. The Park covers $79 \%$ of the island, encompassing two sites of Community Importance as well as one Special Protection Area belonging to the Natura 2000 network. Pantelleria is a microcosm gathering a great variety of natural and human-made landscapes characterized by high levels of complexity embodying the antagonism of two protected 'noble interests': Nature and the environment on the one hand, Culture framed as traditional rural practices on the other. The main challenge of the new-founded National Park is to combine quality and values relating to the domain of Nature, which is expanding, with those expressed by Culture, represented by a wide array of historical rural values at risk due to ongoing abandonment of most remote areas.

Keywords: Pantelleria Island; landscape planning; nature conservation; protected areas; cultural heritage

\section{Introduction}

Over the last several decades, attempts to jointly take into account nature conservation and preservation of cultural heritage have led to new approaches focusing on their interplay considering inherent risks and trade-offs.

This issue is pivotal in Mediterranean countries, where natural factors require humans to adapt their living environment and attune farming to geomorphology [1,2].

The landscape approach, in recognizing the inextricable links between cultural and natural values in the protected areas planning, was tested in the Pantelleria National Park [3].

The island of Pantelleria, southwest of Sicily, gathers in some 83 square Kilometres a wide variety of natural and human-made landscape patterns featuring high complexity and embodying two constitutionally-protected 'noble interests': nature and the environment on the one hand, with tangible and intangible cultural assets linked to traditional agriculture on the other. 'Nature' stands here for a primeval condition of the island and for the current relevance of habitat and species protected by the institution of the National Park. 'Culture' is considered under different standpoints, encompassing traditional rural settlement patterns, farming regimes, as well as intangible assets [4]. 
As a tool introduced by the Framework Law on Protected Areas (Law 394/91), the in-progress Pantelleria Park Plan is expected to accommodate different levels of protection according to relevance, fragility, rarity of natural resources-water, soil, flora, fauna-and other assets, such as traditional rural landscapes, settlements and heritage, deemed worthy of specific protection and management measures [5].

The contribution is organized as follows:

Section 2, General Overview, frames at international and national level the claim for integrating nature and cultural issues, with a specific regard to the planning of protected areas.

Section 3, Materials and Methods, is divided into two paragraphs: in the first a case study of the Pantelleria National Park is described (Section 3.1), in the second, the applied working methodology is carried out (Section 3.2).

Section 4, Results, displays landscape interpretation and applies a multidisciplinary approach at different scales, presenting the proposed Park zoning, coherently with the Italian legislation.

In Section 5, Discussion, strategies and recommendations are given to refine the framework and propose some steps forward.

\section{General Overview}

Expert and general public awareness over tangible and intangible assets have gradually broadened to include all types of living environments, converging over a concept of cultural landscape as a powerful means for social identification, as well as for embracing sustainable development paths [6-8].

Such wide-ranging statute of landscape, also implying semantic shifts in commonly used terminology, claims for joint expert and common knowledge involvement in envisioning and shaping communities' future at every stage of the process, avoiding "options and aims which are too often governed by short-term considerations, narrow view of technology and, in short, an obsolete outlook" [9].

Under the United Nations Educational, Scientific and Cultural Organization (UNESCO) International Conventions, inherent values of heritage to be preserved generally framed within elitist approaches have come to the fore besides and beyond nation-states, in tune with the Age of Enlightenment's main achievements acknowledging culture both in its universal character and its place-specific features [10].

The 1972 World Heritage Convention acknowledges the interaction between nature and artifacts, stressing the fundamental need to preserve the balance between the two $[11,12]$.

At the turn of the Millennium, the Convention for the Safeguarding of the Intangible Cultural Heritage was passed by the UNESCO General Conference. Following the Convention, Intangible Cultural Heritage is defined as "the practices, representations, expressions, knowledge, skills—as well as the instruments, objects, artefacts and cultural spaces associated therewith-that communities, groups and, in some cases, individuals recognize as part of their cultural heritage" (art. 2) [13].

In turn, the International Union for Conservation of Nature and Natural Resources (IUCN), an influential independent body founded in 1948 and composed of both government and civil society organizations, has incorporated within its core mission the so-called Category V "Protected Landscapes", areas shaped by long-standing human-nature relationships, gathering significant ecological, biological, cultural and scenic value [14]. According to IUCN, the protected area management, acknowledged by international bodies such as the United Nations and by many national governments as the global standard, has the aim of "safeguarding the integrity of this interaction is vital to protecting and sustaining the area and its associated nature conservation and other values" [15]. Furthermore, the approach to nature conservation has over time included cultural and landscape disciplines, requiring communities to play an active role in the protection and enhancement of territories [16-18].

Essentially, both IUCN Category V "Protected Landscapes" and World Heritage Cultural Landscapes frame 'landscape' as the result of human relationships with the natural 
environment [18]. The first approach emphasises the natural environment, biodiversity conservation, and ecosystem integrity, whereas the second stresses the relevance of human history, cultural traditions, and social values and aspirations $[3,19]$.

In turn, the European Landscape Convention (ELC) outlines the concept of landscape as "an area, as perceived by people, whose character is the result of the action and interaction of natural and/or human factors, [ ... ] an essential component of people's surroundings, an expression of the diversity of their shared cultural and natural heritage, and a foundation of their identity" [20]. In addition to taking into consideration both the ecological landscape approach and the cultural landscape one, the ELC frames landscape as a common ground (including natural, rural, urban and peri-urban areas) for sharing opinions and visions, targeting landscape quality objectives, and ultimately achieving wise integration between different policy design measures, actions and tools as for landscape protection, planning and management.

Moreover, within the 10th Conference of the Parties (COP 10) to the Convention on Biological Diversity (CBD) (2010) on the new Strategic Plan for Biodiversity to 2020, the Aichi Target 11 addresses relevant innovations for protected areas. First of all, ecosystems conservation measures are framed within a place-specific approach [21]. Secondly, they encompass protected sites within a wider system of landscape and seascape.

Since ELC and Aichi Targets converge about the need to adopt an inter-sectoral and multiscale approach, it is no coincidence that their statements have brought to light preexisting coordination problems among different institutions in charge of conservation issues, whilst enlarging the arena of stakeholders involved [22-24].

In Italy, despite the enforcement of the far-sighted Framework Law on Protected Areas, only few experiences in the planning of protected areas, frame landscape as a result of place-specific rules accounting for a sustainable balance between human activities and the environment, since Park Plans are mainly concerned with habitat protection, overlooking local and cultural development issues [25-33]. Furthermore, whereas planning and management practices tend today to use cross-cutting approaches, the split of competences is the rule: the Ministry for Ecological Transition is entrusted with the protection of nature, the Ministry of Culture is in charge of heritage and landscape, the Ministry of Agricultural, Food and Forestry Policies has recently come to the fore in overseeing the National Register of Historical Landscapes, based on criteria of significance, integrity and vulnerability (Table 1). In addition to institutional logics and unavoidable different perspectives, the essential concern is the lack of governance tools paving the way for dialogue and mediation among specific institutional missions and related interests and values [4].

Table 1. Institutional logics. Main purposes, legislative framework, planning and management tools.

\begin{tabular}{cc}
\hline Ministry & Main Issues \\
\hline $\begin{array}{c}\text { Ministry of } \\
\text { Culture }\end{array}$ & $\begin{array}{c}\text { Entrusted with: culture, protection and } \\
\text { conservation of artistic sites and landscape. }\end{array}$ \\
$\begin{array}{c}\text { Ministry for } \\
\text { Ecological Transition }\end{array}$ & $\begin{array}{c}\text { Entrusted among others with: the protection of } \\
\text { biodiversity, ecosystem and marine and coastal } \\
\text { resources, the safeguarding of land and waters, } \\
\text { policies to combat climate change and global } \\
\text { warming, sustainable development, energy } \\
\text { efficiency and the circular economy. }\end{array}$ \\
\hline
\end{tabular}

Ministry of Agricultural, Food and Forestry Policies
Entrusted with: government policy on agriculture, forests, food and fisheries at national, European and international level

\section{Tools}

For Landscape planning the Decree n. 42/2004 provides Landscape Plans in co-decision between the Regions and the Ministry [34].

For National Parks and Protected Areas, the Law 394/91 established a Park Authority in charge to develop the Regulations, the Park Management Plan and the Multi-Year Economic and Social Plan.

The "National Register of rural landscapes of historical interest, agricultural practices and traditional knowledge" is part of the homonymous Observatory established by Decree n. 17,070 of 19 November 2012. The implementation of this tool is not mandatory. 


\section{Materials and Methods}

\subsection{Case Study}

The island of Pantelleria is spread over an area of 8453 hectares, located in the centre of the Sicilian Channel in the Province of Trapani (Sicily), on the rift that divides the African continent from the European one (Figure 1).

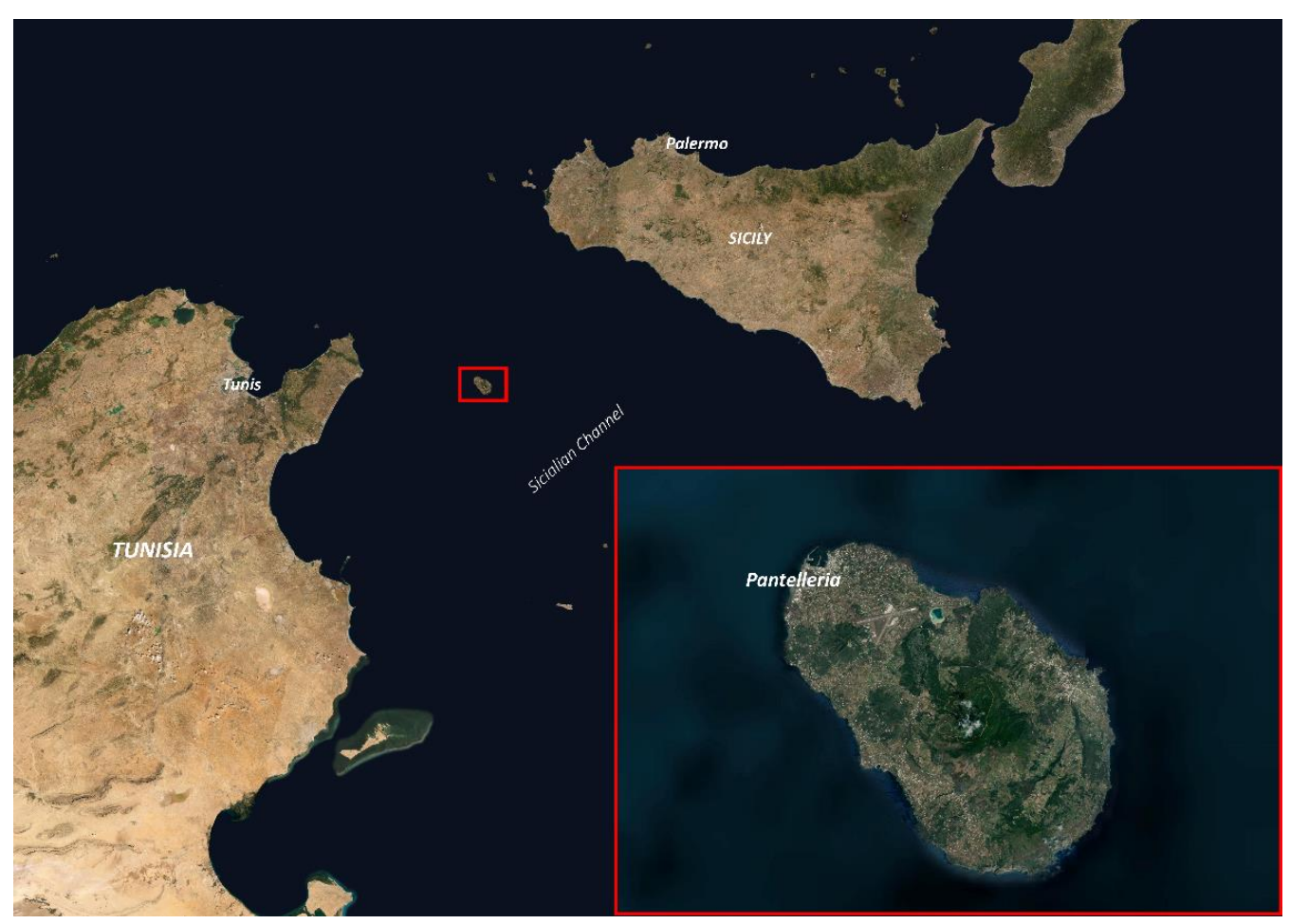

Figure 1. Satellite view of Pantelleria. Source: Authors' elaboration.

The island's peculiar geomorphology due to its volcanic origin, as well as local microclimates favourable to endemic species of great value, are features of utmost interest [1]. In turn, rural landscapes have been shaped from the sea level up to the higher altitudes, taking hold of even the steepest slopes. As a matter of fact, terrace systems have been around since the protohistoric age: continuity over time of such settlement patterns embedding formal, functional and symbolic values conveys the idea of a human-nature balance achieved at great sacrifice [35-38]. Rural landscape encompasses several types of centuries old artefacts erected in local lava stone evidencing the hardships of peasants' lives, including steepness (terrace systems), droughts (storing water devices) and extreme windiness (pits up to 80 centimetres deep for protecting crops). Using and handing down specific cultivation techniques, the community of Pantelleria has modelled on the lava and available lands an agricultural mosaic of traditional non-irrigated crops protected by dry stone walls and terraces "of extraordinary aesthetic charm and great scenic impact" covering more than $70 \%$ of the entire island [39-42].

From the Bronze Age onwards, the nature of the locally available stone has determined the chromatic and stereotomic aspects of the landscape [43]. Terrace farming constitutes the most massive and planned intervention carried out by the ancient populations settled in the north-western side of the island, where extensive land appropriation served both for building residential units and for the arrangement of monumental burial chambers. Ever since, agriculture has been developing from early subsistence in ecological niche areas alone (slopes, small plateaux) to rural activities extended on large terraced areas accounting for division of labour and a social structure capable of accumulating resources $[43,44]$.

According to the Bourbon Land Registry (1833), 69\% of the island was cultivated, and vineyards occupied $12.7 \%$ of the area, equal to 1054 hectares. Zibibbo, currently one of the 
rarest grapes in the world, was at the time grown together with other varieties, especially for wine: a modest crop, flanked by cotton cultivations that accounted most for the island's economy [45-47]. The year of the definitive consecration of Pantelleria to agriculture is 1845 , when the abolition of the fiefdom created the conditions for the land to pass into the hands of peasants, until then almost slaves. According to the 1929 Cadastre, $84 \%$ of the island was covered with crops of which $76 \%$ were zibibbo vineyards $[48,49]$.

From the 1950s onward, the ageing of the population and the immigration of young people has negatively impacted cultivated area, decreasing from 5200 hectares to currently 1400 hectares, accounting for $18 \%$ of the island's surface [50,51].

As for settlement features, aside from the main town with its port and urban facilities, Pantelleria is dotted by hamlets and traditional buildings, called dammusi, originally linked to agricultural activities and intermittently inhabited [52]. From the 19th century onward, most of the rural arrangements next to the dammusi such as gardens and other agricultural annexes were also built [53-55].

With the advent of tourism in the 1960s, new houses built from scratch were inspired by this basic typology, larger in size, often made with stone on the outside. Scattered low density settlements, called contrade, are present in the form of nebulae or filaments, along the main infrastructures [43].

Today the island is home to about 8000 year-round inhabitants rising to 40,000 in summer, applying significant pressures on the habitat, public services and infrastructure. Despite many changes, identifiable features of the Pantelleria landscape remain in place and can be glimpsed across the island through spontaneous vegetation taking hold of cultivated land (Figures 2 and 3) [38-40,50].

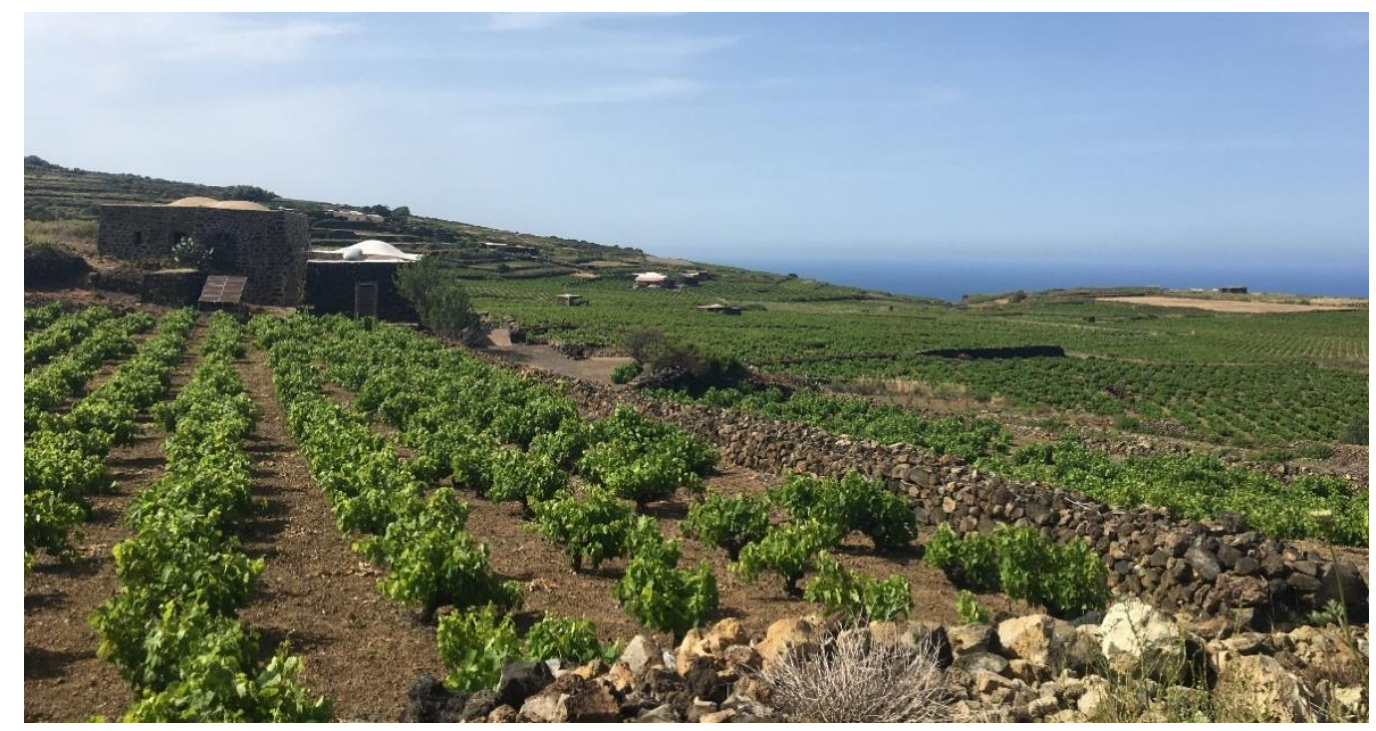

Figure 2. Pantelleria traditional rural landscape in the hamlet of Mueggen. Source: Romina D'Ascanio, June 2021.

The inscription in the UNESCO Intangible Heritage List of both the Traditional agricultural practice of cultivating the vite ad alberello of the community of Pantelleria (2014), and the Art of drystone walling, knowledge and techniques (2018), has brought the island to international attention, reinforcing its achievement with the market success of the Passito wine awarded at the Paris International Exhibition (1900) and eventually inscribed in the list of typical Italian wines (1936) [56].

The Pantelleria National Park has been the latest established in Italy (Decree of the President of Republic, 07.28.2016, Istituzione del Parco Nazionale Isola di Pantelleria e dell'Ente Parco Nazionale Isola di Pantelleria) (16A07194). It is the first one in Sicily, covering $79 \%(6,560 \mathrm{ha})$ of the surface and encompassing two Sites of Community Importance 
(ITA 010,019 Montagna Grande e Monte Gibele, ITA 010,020 Area Costiera, Falesie e Bagno dell'Acqua), as well as one Special Protection Area (ITA 010,030 Isola di Pantelleria e Area Marina Circostante) belonging to Natura 2000 network.

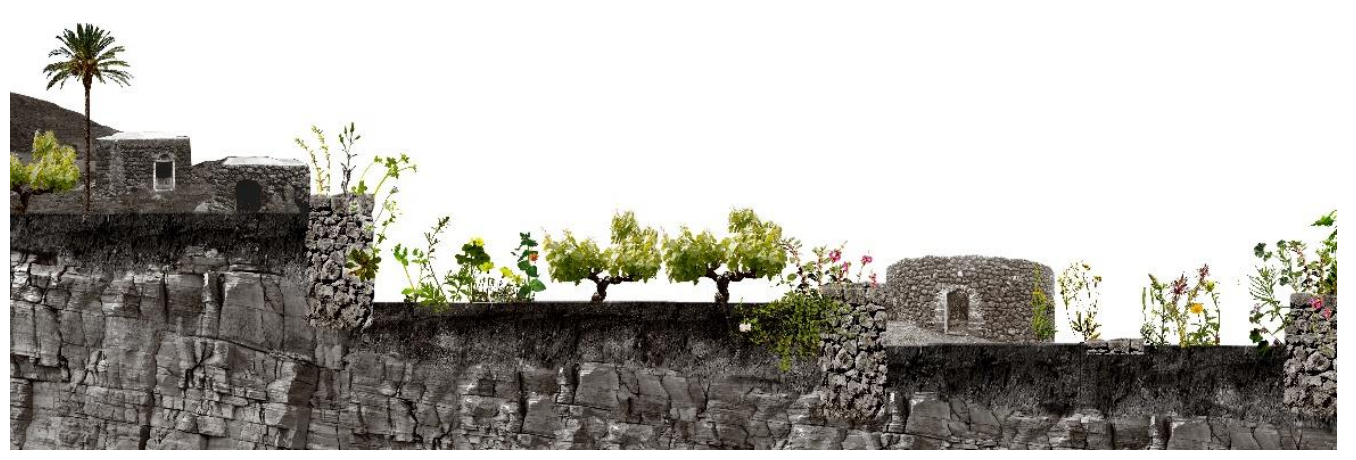

Figure 3. Cross-section of the Pantelleria rural landscape. Graphic elaboration: S. Savelli.

In 2018, a significant part of the Park area was included in the Italian National Register of Historic Rural Landscapes [57,58].

Pantelleria hosts various types of land uses in different proportions, as shown in Table 2 and Figure 4 below. Crops account for almost 37\%, ranging from vineyards to cultivated fields and some olive trees. Shrubs and maquis follow, accounting for almost a quarter of the total land use. Grasslands and pastures are the next group, covering 17\% of the island. Close by are woods which cover 16\% of Pantelleria. Other land uses have quite low values, with the notable exception of the built environment (around 5\% of the island surface).

Table 2. Land use.

\begin{tabular}{ccc}
\hline Land Use & Area (ha) & Percentage \\
\hline Built environment & 425.66 & $5.10 \%$ \\
Crops & 3078.75 & $36.91 \%$ \\
Woods & 1371.01 & $16.44 \%$ \\
Grasslands and pastures & 1399.45 & $16.78 \%$ \\
Shrubs and maquis & 2035.26 & $24.40 \%$ \\
Other (cliffs, vegetation, lakes and lagoons) & 31.55 & $0.38 \%$ \\
Total (percentages were rounded so the total & 8341.67 & $100 \%$ \\
value might be higher than 100) & & \\
\hline
\end{tabular}

Traditional landscapes represent a geophysical result of long-standing interactions between communities and the environment; the methodology has addressed the issues of environmental conservationism and those related to human development activities [59-62].

Despite falling within the IUCN Category 2 "National Park", the Pantelleria Park can be framed, according to the protected areas landscape approach, within Category V "Protected Landscapes/Seascapes" [18,19,63-66]. This approach is in line with the Italian Framework Law on Protected Areas, which recommends holding into account the natural and environmental values with the historical, cultural, anthropological and traditional ones, capturing the communities' identity.

In order to overcome incongruity and overlapping between protected areas zoning and visible features of cultural landscape, the following paths have been developed: (i) a close look rooted in natural features, cultural heritage and traditional rural practices, identifying some recurrent schemes and arrangements typical to the island, and (ii) a large-scale vision on the identification of common perimeters, called Landscape Systems, for the proposal of the Park Plan zoning. 


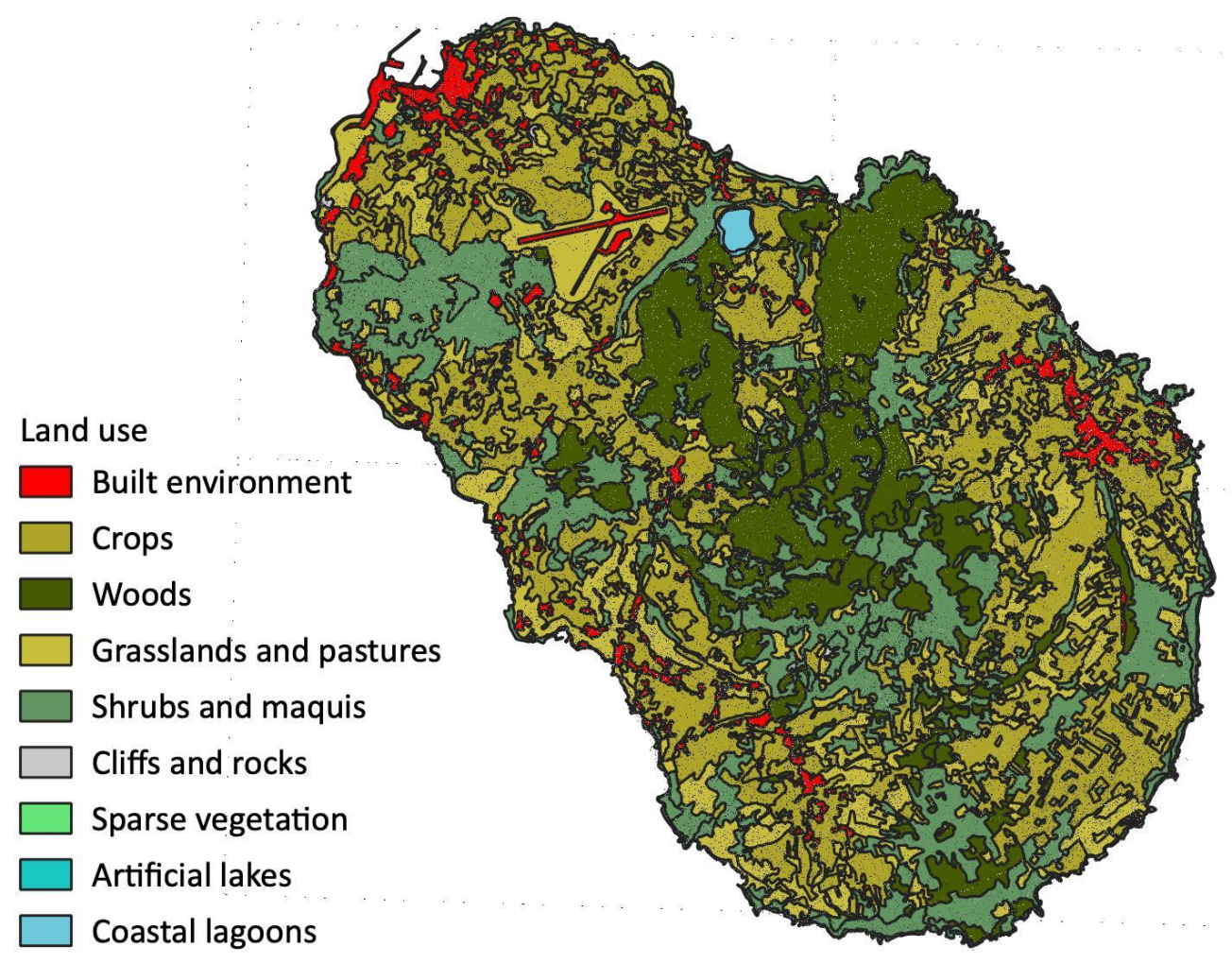

Figure 4. Land use according to CORINE Land Cover.

\subsection{Methodology to Read the Landscape at Different Scales}

The first step, in accordance with the "National Register of rural landscapes of historical interest" acknowledges that the Pantelleria terrace systems still in place and cultivated, consist as listed in the landscape matrix of recurring landscape elements, features and their countless variants (construction typologies and settlement patterns) at small scale (Figure 5). This focus investigates rural heritage and practices rooted in terrace systems, arrangements closely related to cultivation techniques that have been taming even the most extreme slopes. Such structures, along with walls serving as property limits and/or providing crop protection, are entirely created through dry construction methods.

The second step focused on the delimitation of the Landscape Systems and Subsystems as a possible implementation of the spatial zoning annexed to the Institutive Decree of the Park (in view of the adoption of the Plan of the Pantelleria National Park (PPNP)). Landscape Systems are generally intended as homogenous areas with specific structural features, based on the criteria adopted for their classification (CORINE Land Cover), whose advisable development trajectories are to be framed by specific guidelines.

Accordingly, to highlight the deep human-nature relationships, the investigation was carried out reviewing the boundaries within the Landscape Plan (currently under review). A main issue addressed was to comply to the Legislative Decree 42/2004, the SCI/SAC Management Plan, and the prescriptions of the PPNP for: (i) scientific purposes (bridging the gap between the two realms stressing the need to comprehensively address the humannature interplay), and (ii) practical aims (accommodating overlay mapping procedures and related criteria both within the National Park Plan underway as well as to the forthcoming Landscape Plan).

Table 3 below summarises the phases described below for the determination of the new zoning, that will be fully defined in the results section. Our proposal will be the draft that the Park Authority, after further in-depth checks, will use in the official co-design planning process of the Park Plan with the local community and regional and national institutions. 


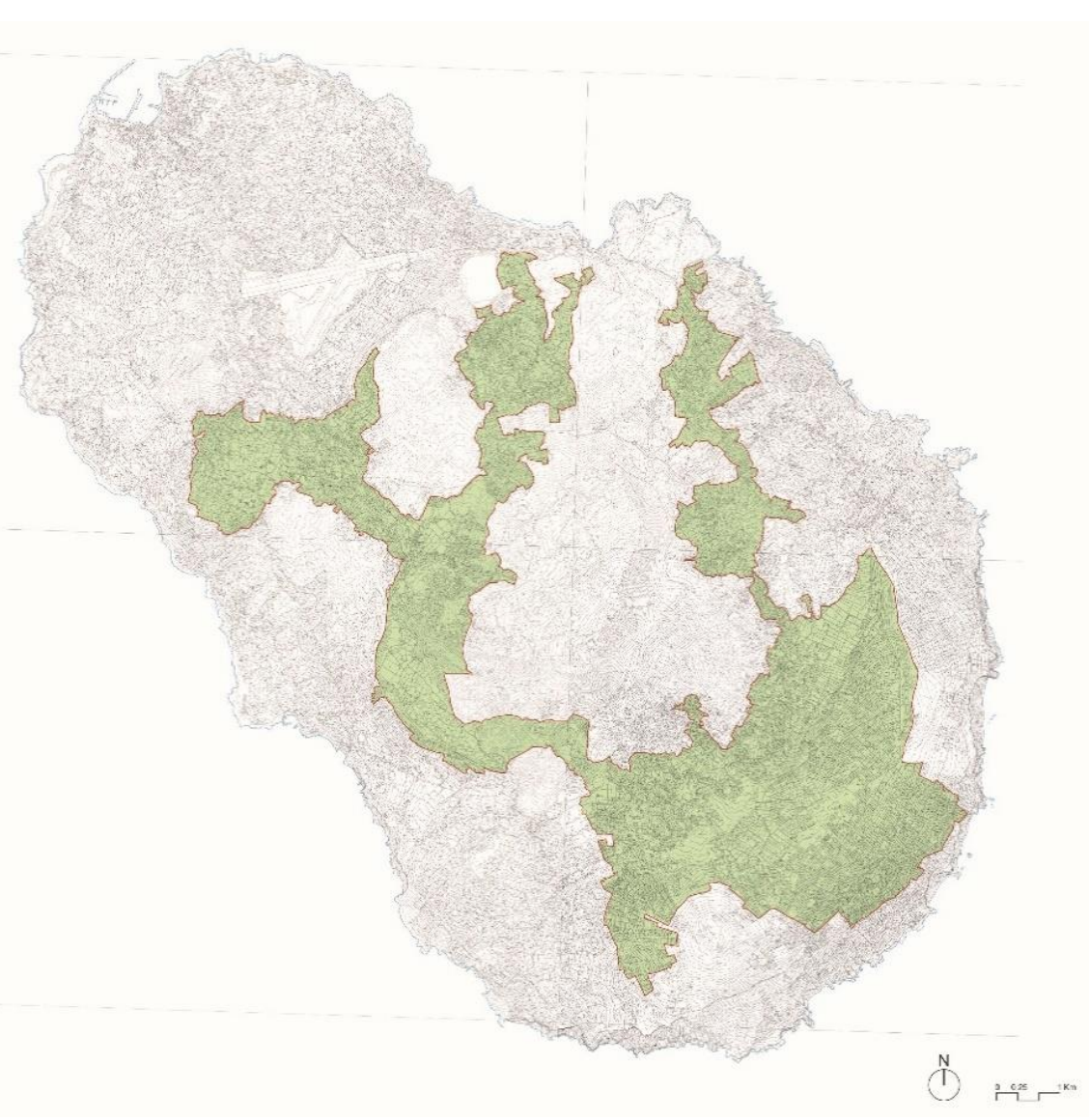

Figure 5. Area of the Historical Rural Landscape (in green): Source: Pantelleria candidacy dossier to the National Register of Historical Rural Landscapes.

Table 3. Zoning process: overlay, reconfiguration and assessment.

\begin{tabular}{|c|c|c|}
\hline Phase & Documents Used & Description of the Process \\
\hline $\begin{array}{l}\text { Overlay of the original Park zoning } \\
\text { to the regional base map (CTR) }\end{array}$ & $\begin{array}{l}\text { Park zoning; Regional base } \\
\text { map }\end{array}$ & $\begin{array}{l}\text { The three zones of the park were overlaid to the regional } \\
\text { base map as such: Zone 1, (relevant naturalistic, } \\
\text { agricultural and historical landscape interest, with no or } \\
\text { negligible urbanisation); Zone 2, (naturalistic, agricultural } \\
\text { and/or historical value with limited urbanisation); Zone 3, } \\
\text { (landscape and/or historical value, with high } \\
\text { urbanisation). }\end{array}$ \\
\hline $\begin{array}{l}\text { Overlay of the original Park zoning } \\
\text { to the Landscape plan areas }\end{array}$ & Park zoning; Landscape Plan & $\begin{array}{c}\text { The overlay of the Park zoning to the } 75 \text { Landscape } \\
\text { Plan areas. }\end{array}$ \\
\hline $\begin{array}{l}\text { Targeted reconfiguration of the } \\
\text { Landscape plan areas }\end{array}$ & Park zoning & $\begin{array}{l}\text { After the overlay, the researchers were able to identify } \\
8 \text { Landscape systems and } 47 \text { Subsystems within the } \\
\text { National Park. This was carried out by (i) acknowledging } \\
\text { the peculiarity of the coastal areas, (ii) aggregating some } \\
\text { landscape areas with similar characteristics and protection } \\
\text { regimes, and (iii) re-design of the settlements } \\
\text { (villages and hamlets). }\end{array}$ \\
\hline Environmental quality assessment & Park zoning; Habitat map & $\begin{array}{l}\text { The } 47 \text { Subsystems were then overlayed with the map of } \\
\text { habitat quality within the management Plan of the Natura } \\
2000 \text { sites on the island. The values divided in } 3 \text { classes } \\
\text { and weighted for each Subsystem, with values ranging } \\
\text { from } 0.09 \text { to } 0.87 \text {. }\end{array}$ \\
\hline
\end{tabular}


Although different in their rationales, these geographies bear common elements, such as a fair coincidence of the main perimeters. In order to check whether and how spatial data match or diverge, GIS processing has been carried out according to the following criteria: (i) to keep the classification of the Plan of the Pantelleria National Park (PPNP) annexed to the Decree as unchanged as possible (Figure 6), and (ii) to streamline the regulatory framework provided by the Landscape Plan (LP). Here, the 75 areas subjected to different zoning regulations have been reduced by uniting neighbouring zones whenever they belonged to the same natural protected area according to Decree of the Park, if they displayed quite similar, if not identical, morphological, landscape, environmental and settlement features.

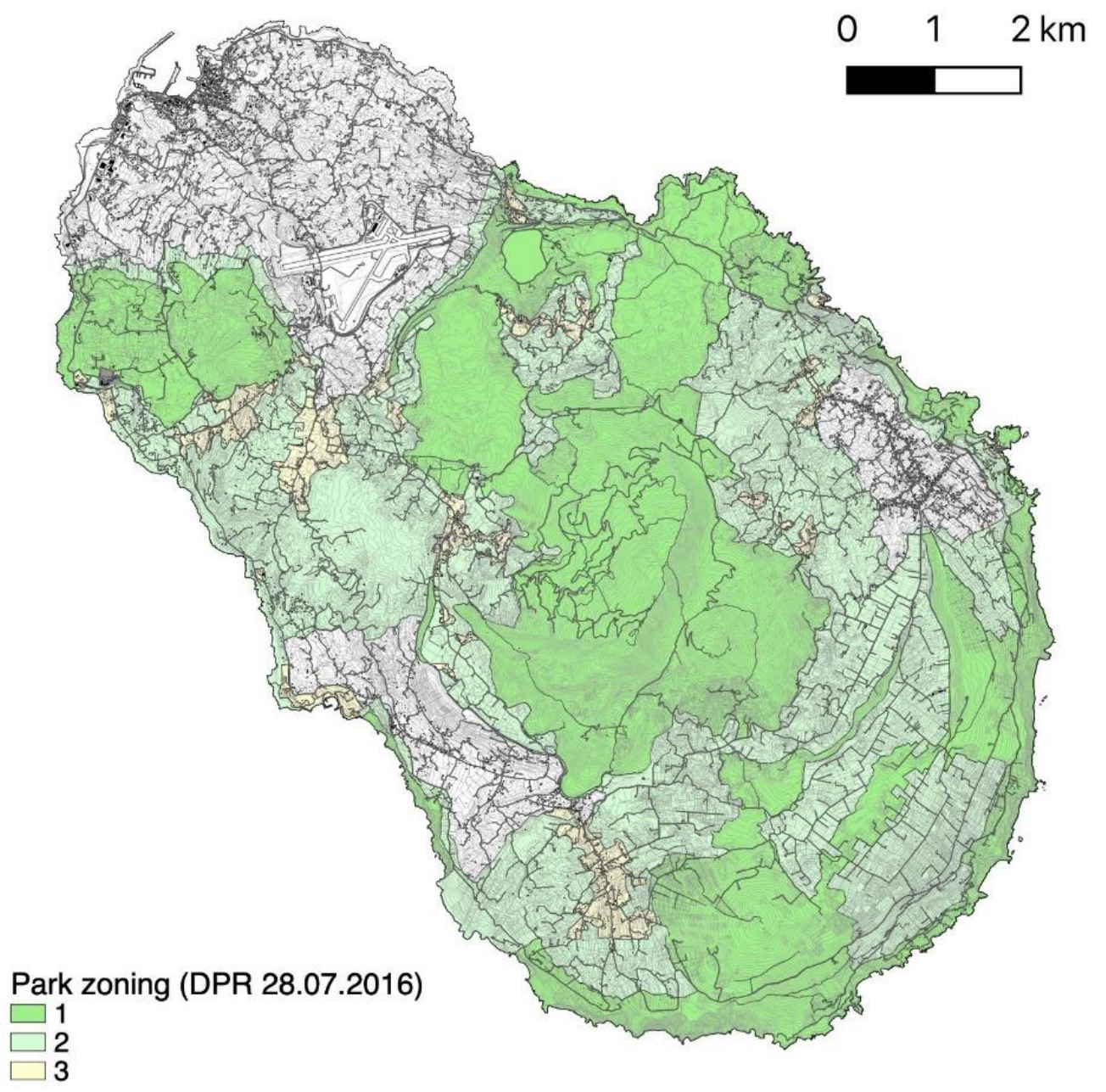

Figure 6. Borders and zoning of the Pantelleria National Park. (Source: Authors' elaboration from DPR 28 July 2016).

The logic behind such procedure had two main reasons, namely: (i) to convey to collective perception the idea of deep linkages among protection regimes, characteristics of places and their denomination, inherent in toponyms and therefore in local history; (ii) to lay the foundations for streamlining the regulatory framework of the PN, avoiding the risk of undue fragmentation. While previously divided among the neighbouring landscape areas, the coastal area was acknowledged as a peculiar one in the island, deserving high protection, and was thus separated from the rest. This was carried out to highlight the peculiarity of the cliffs and their vegetation, two habitats acknowledged by the management Plan of the Natura 2000 sites on the island. Moreover, the urbanised areas were re-designed according to their evolution over 100 years according to cadastral maps and archive references. 
This re-design activity resulted in the identification of 8 Landscape Systems and 47 Subsystems, that will be described in the results section of this article.

In order to define the environmental quality of each Subsystem, all 47 were overlaid with the map of habitat quality within the management plan of the Natura 2000 sites. The value shown in Figure 7, between 0 and 14, accounts for the presence of species in each area. More precisely, these values result from the sum, for each habitat area, of the number of 14 relevant faunistic species that are suitable for their habitat. This is not an indicator of environmental quality per se, but can be considered as a proxy.

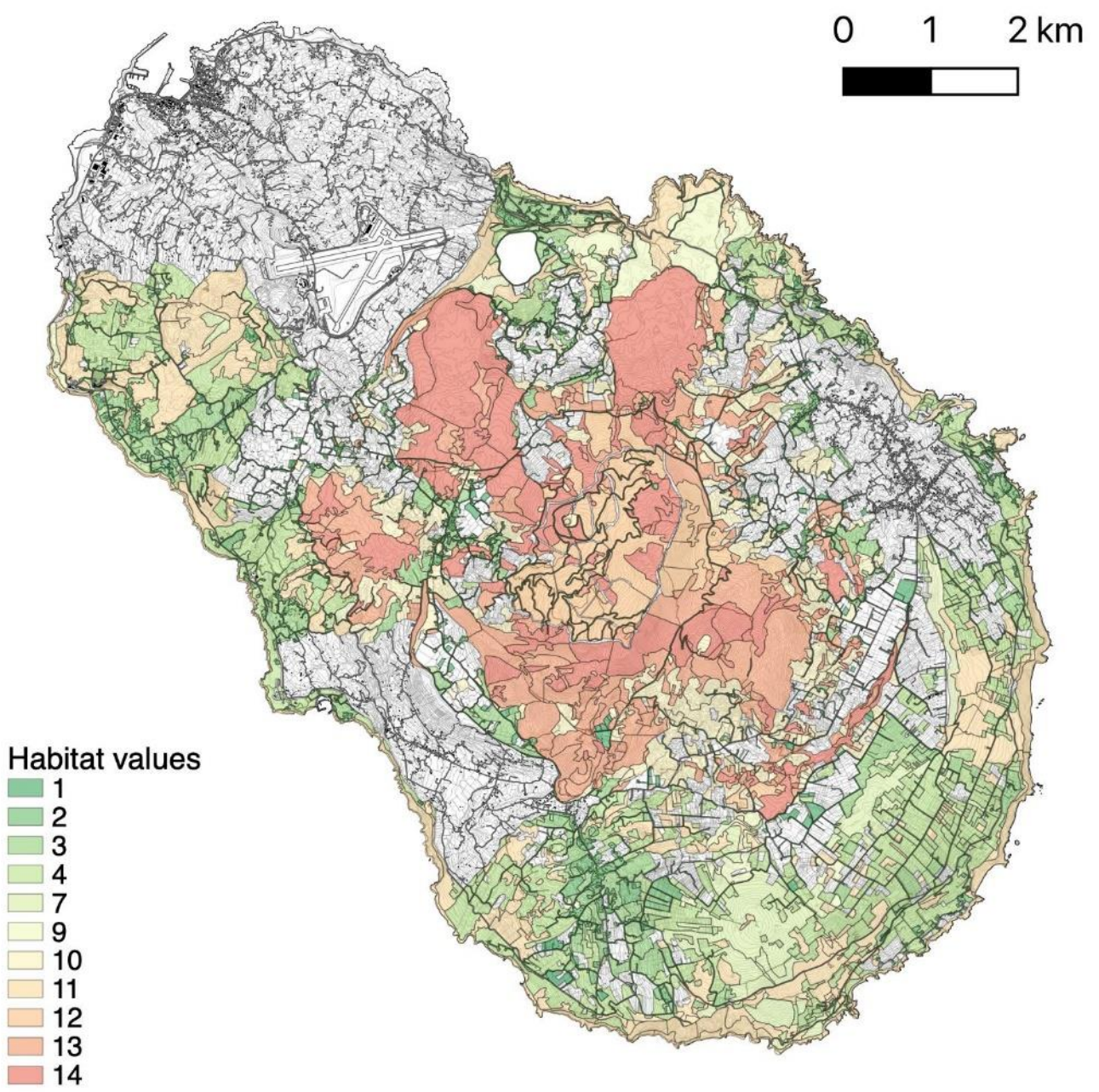

Figure 7. Habitat values. (Source: Authors' elaboration from the management Plan of the Natura 2000 sites).

For each Landscape Subsystem, we calculated the percentage of the surface of each habitat in the area and then weighted each percentage according to three classes:

- $\quad 0-3$ species habitats: 0.15

- $\quad 4-10$ species habitats: 0.5

- $\quad$ 11-14 species habitats: 0.9

For instance, when a habitat area covered 35\% of a Subsystem, then the habitat value was weighted with the area percentage. The weighted values for each habitat area were then summed up within each Landscape Subsystem, thus resulting in a value between 0.09 and 0.87 , which we defined as a proxy environmental quality index. This allowed the development of a map of the Subsystems divided in 10 classes of increasing quality, which the reader can find in the next section. 


\section{Results \\ 4.1. Features and Patterns}

Culture and nature have long been at work conveying identities shaped by knowledge, skills and practices embedded in a huge variety of landscape features and patterns resulting from centuries-old dwelling and farming traditions [38,39]. The matrix collects the agricultural and natural landscapes still in place, demonstrating the exceptional adaptation and resilience acquired by the community as well as the cultivated species $[43,45]$. Recurrent patterns and shapes at different scales convey peculiar human-nature interplay (Table 4) [67,68].

The spatial complexity of the agro-ecological mosaic, due to the intrinsic features linked to the geological conformation of the island and the extreme variability of its microclimate, confers a high ecological and perceptive value [69]. However, abandonment phenomena started after the Second World War, due both to morphology and land fragmentation, forbidding the introduction of mechanization in agriculture. Consequentially, spontaneous vegetation occupied previous crop areas, mainly at high altitudes [70-72].

Table 4. Landscape features and patterns.

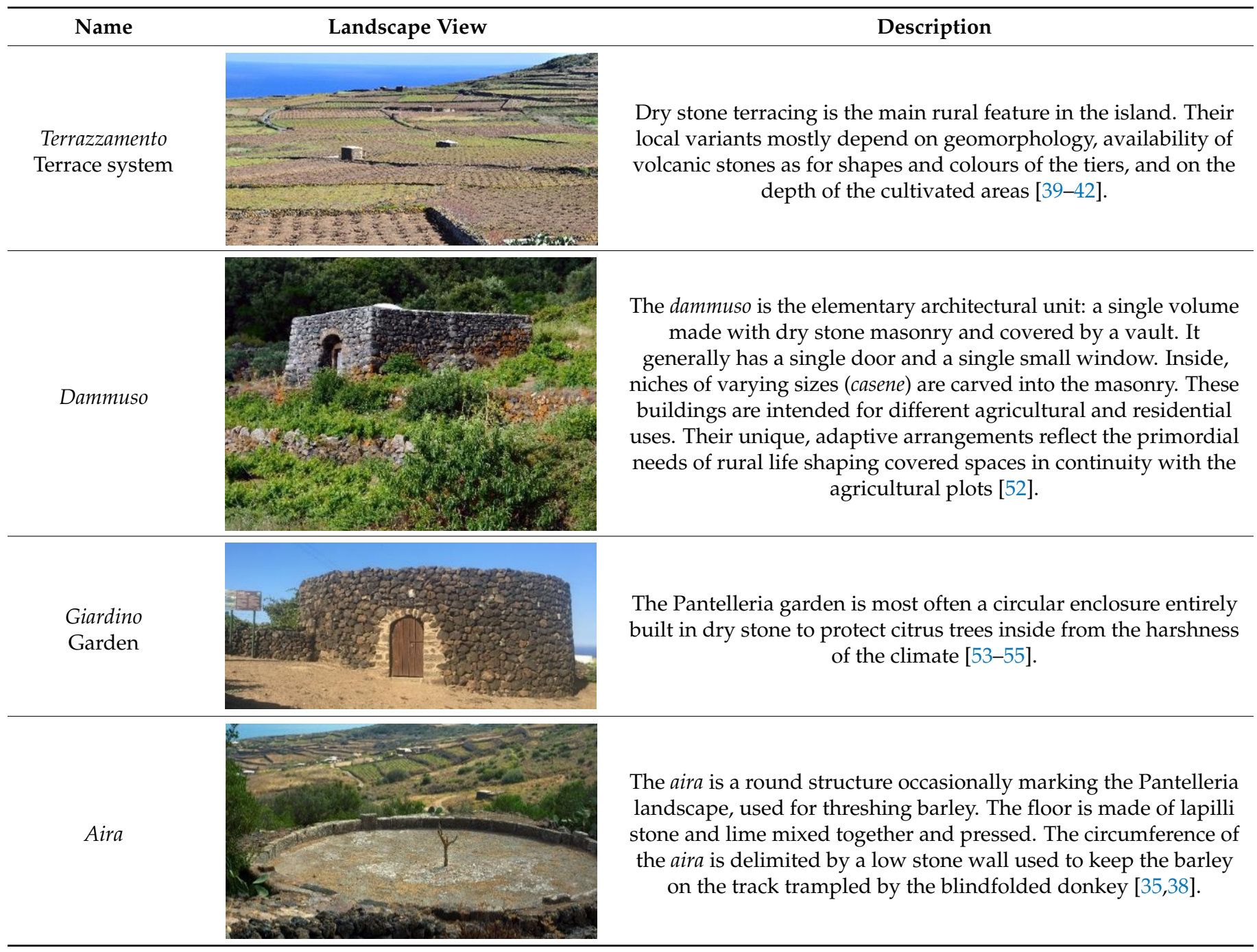


Table 4. Cont.

\begin{tabular}{ccc}
\hline Name & Dandscape View & Description \\
\hline Sesi & $\begin{array}{c}\text { Sesi are megalithic constructions present in the area of Mursia and } \\
\text { Cimillia built by a northern African population who settled on } \\
\text { the island about 5000 years ago during their invasion of } \\
\text { southwestern Europe. They are truncated cone burial chambers } \\
\text { with an elliptical or circular plan. They were erected outside the } \\
\text { village walls on flatter areas. Nowadays, the Sesi Archaeological } \\
\text { Park was established }\end{array}$ \\
\hline
\end{tabular}

The most widespread crop is the vine, the Pantelleria sapling, cultivated in pits about $20 \mathrm{~cm}$ deep, useful for accumulating rainwater and protecting the grapes from the wind. The Zibibbo variety is prevailing on the island, providing flavoured table grape, raisins and, above all, wine, notably the worldwide well-appreciated Passito di Pantelleria [51]. The traditional

agricultural practice of cultivating the vite ad alberello (head-trained bush vines) of the community of Pantelleria was inscribed in 2014 in the Unesco WHL.

Olive trees are domesticated and almost trunkless. Their branches, weighed down by large stones and tied by vine shoots, bent and placed on the ground, imposing a horizontal, creeping and twisted development [73].

Olive groves
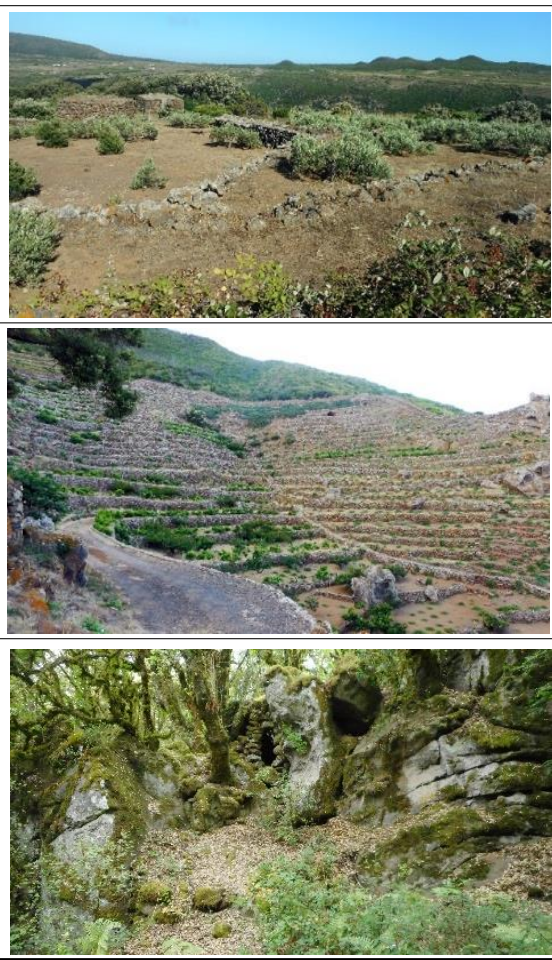

The cultivation of the caper is the second most important on the island. In past times, it was collected from spontaneously born plants especially on sunny rock walls. Since the 1970s, the caper plant no longer occupies marginal lands, yet extends over small specialized plots, especially in the South West areas, where the climate is more arid and warm $[74,75]$.

The low Mediterranean scrub grows from sea level up to $250 \mathrm{~m}$ of altitude; above $250 \mathrm{~m}$ a shrub-arboreal vegetation is the main feature. At altitudes above $500 \mathrm{~m}$ and in the valleys, the Quercus ilex woods are located. The thick layer of humus is home to numerous species, belonging to the mesofauna. [76-78]

\subsection{Landscape Systems and Subsystems, Zoning Proposal}

The last paragraph of the previous section detailed the methodology that brought about the proposal of 8 Landscape Systems and 47 Subsystems, as well as the possible new zoning, which are the focus of this paragraph of the article. Alongside the Systems and Subsystems, there are the settlements Subsystems (Sistema insediativo): 6 Contrade; 8 Nuclei Rural; and, 3 Altri Insediamenti. Table 5 below explains their distribution and naming. 
Table 5. Landscape Systems and Subsystems.

\begin{tabular}{cc}
\hline Landscape System & Landscape Subsystem \\
\hline $\begin{array}{c}\text { Falesie e coste marine } \\
\text { (Coastal areas) }\end{array}$ & $\begin{array}{c}\text { Costiera Dietro Isola, Costiera di Jakhe, } \\
\text { Costiera Gelkhamar, Costiera Khaggiar, } \\
\text { Costiera Punta Tracino, Costiera Scirafi, } \\
\text { Marina di Suvachi }\end{array}$ \\
\hline $\begin{array}{c}\text { Lago Spechio di Venere } \\
\text { (Lake) }\end{array}$ & Bagno dell'acqua, Piane del Lago, \\
& Versanti del Lago \\
\hline $\begin{array}{c}\text { Grandi rilievi (Mountains) } \\
\text { Kuddie maggiori (Major hills) }\end{array}$ & $\begin{array}{c}\text { Montagna Grande e Kuddie circostanti, } \\
\text { Monte Gibele, Favara }\end{array}$ \\
\hline $\begin{array}{c}\text { Colate laviche fratturate } \\
\text { (Fractured lava flows) }\end{array}$ & Dietro Isola, Kuddia Sciuvechi \\
\hline
\end{tabular}

Orli Calderici (Caldera edges)

Orlo di Monastero e Zighidi, Orlo Ghirlanda, Orlo Zinedi, Serra Ghirlanda

Coastal subsystems were carved out of the adjoining subsystems, in accordance with land morphologies and excluding inhabited areas, such as ports and

hamlets. These areas, featuring a rocky environment, include vital habitats that represent the interface between sea and land.

Lago Specchio di Venere contains an important habitat, a freshwater lake, that is threatened by nearby human activities. The Subsystems distinguish among the actual lake, the adjacent plains, and the slopes.

This system contains mountain areas with highest environmental quality

Some areas of these Subsystems belong to the coastal ones. They feature high environmental quality due to an increased presence of natural habitats

One Subsystem (Orlo di Monastero e Zighidi) was slightly expanded in order to include an area worthy of protection. Some of these areas also feature high environmental quality due to an increased presence of natural habitats.

Benimingallo, Bugeber Nord, Bugeber Sud, Sotto Scauri, Dietro Isola, Khaffefi, Khamma Fuori, Khania, Kattibuale,

Maccotta, Madonna delle Grazie,

Versanti dei Coltivi e degli Ex Coltivi (Slopes of cultivations and former cultivations)

Mueggen, Nikà, Penna, Piano del Barone,

Salto la Vecchia, Sopra Ghirlanda, Sopra Sibà, Sotto Khamma Tracino, Tikirriki
Some areas of these Subsystems belong to the coastal ones. Certain cultivated areas faced some level of abandonment in recent decades, and were gradually replaced by natural habitats, namely shrubs and grasslands pertaining to the Natura 2000 codes 5330 and 6220.

Agriculture develops horizontally, resisting and strengthening in the absence of morphological impediments.
Pianure coltivate
(Cultivated plains)

Piana Monastero, Piana Ghirlanda

\section{Sistema}

insediativo-Contrade

(Settlements-Contrade)

Sistema insediativo-Nuclei

Rurali (Settlements-Rural hamlets)

Sistema insediativo-Altri insediamenti

(Settlements-Other)
Bugeber Contrada, Bukkuram, Grazia, Rekale, San Vito, Sibà

Cala Levante e Tramontana, Gadir Porto, Kufurà, Martingana, Monastero, Mueggen, Runcuni Pigna e Cittadella, Venedisè

Punta Fram, Porto di Scauri, Dissalatore
Most settlements had their boundaries modified, taking or giving their areas from or to neighbouring Subsystems. The Contrade are the most important settlements within the Park, often hosting a church.

Nuclei rurali are lesser settlements, being often simple groups of houses with a local name. Other settlements are quite recent, often built for touristic reasons.

Following the directions of the Table 5 above, the boundaries of the Sub-systems were finely modified in order to improve the management of each area (Figure 8). In some cases, cultivated areas were separated from more natural ones, in order to provide the best suited protection for each area. Another important change regarded settlements' boundaries, according to a thorough analysis of these peculiar villages and hamlets located within the park.

As a follow-up to the map of the management plan of the Natura 2000 sites as shown in the previous section, a map of the Subsystems takes into account 10 classes of habitat quality (Figure 9). 


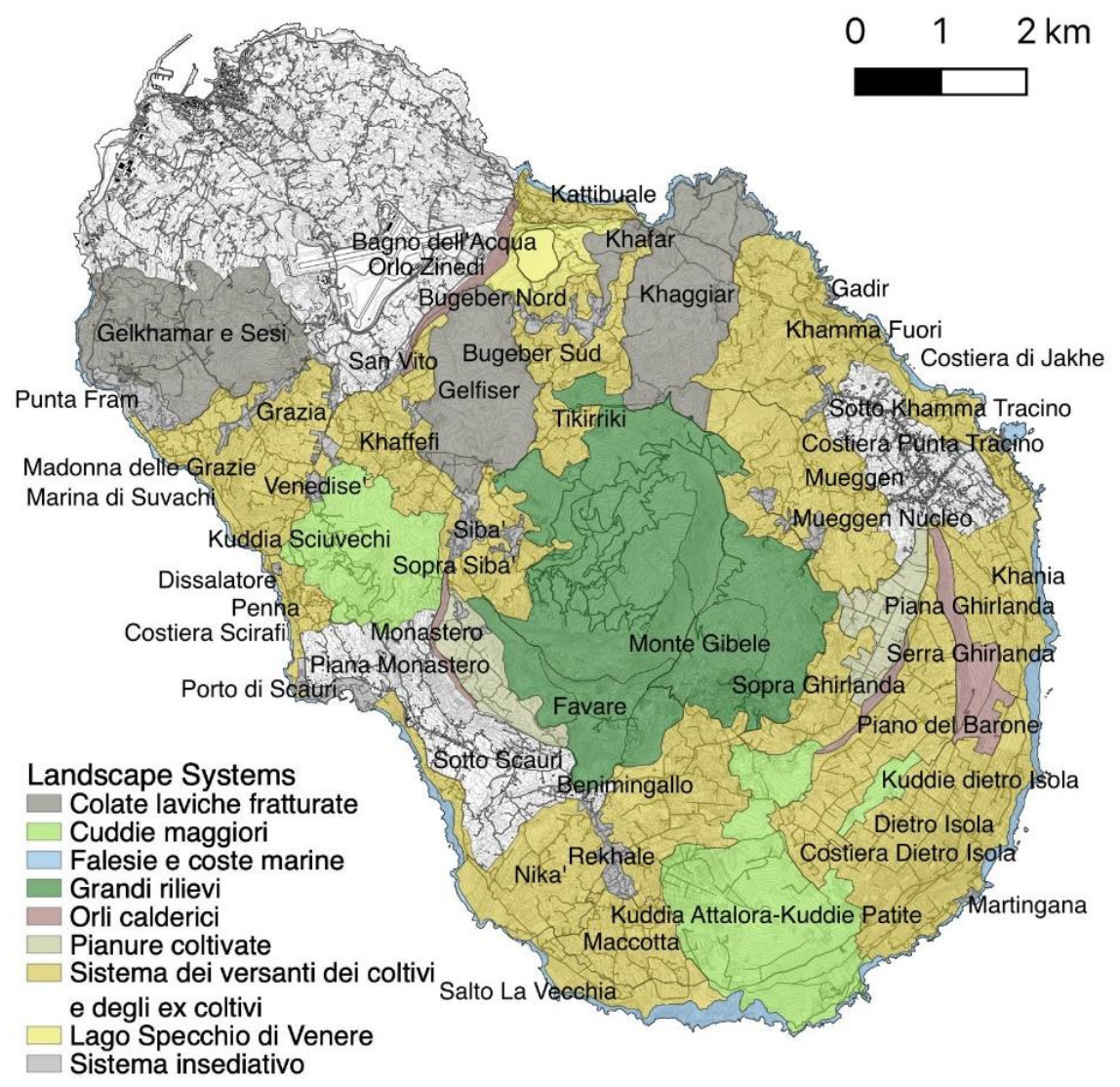

Figure 8. Landscape Systems and Sub-systems. (Source: Authors' elaboration).

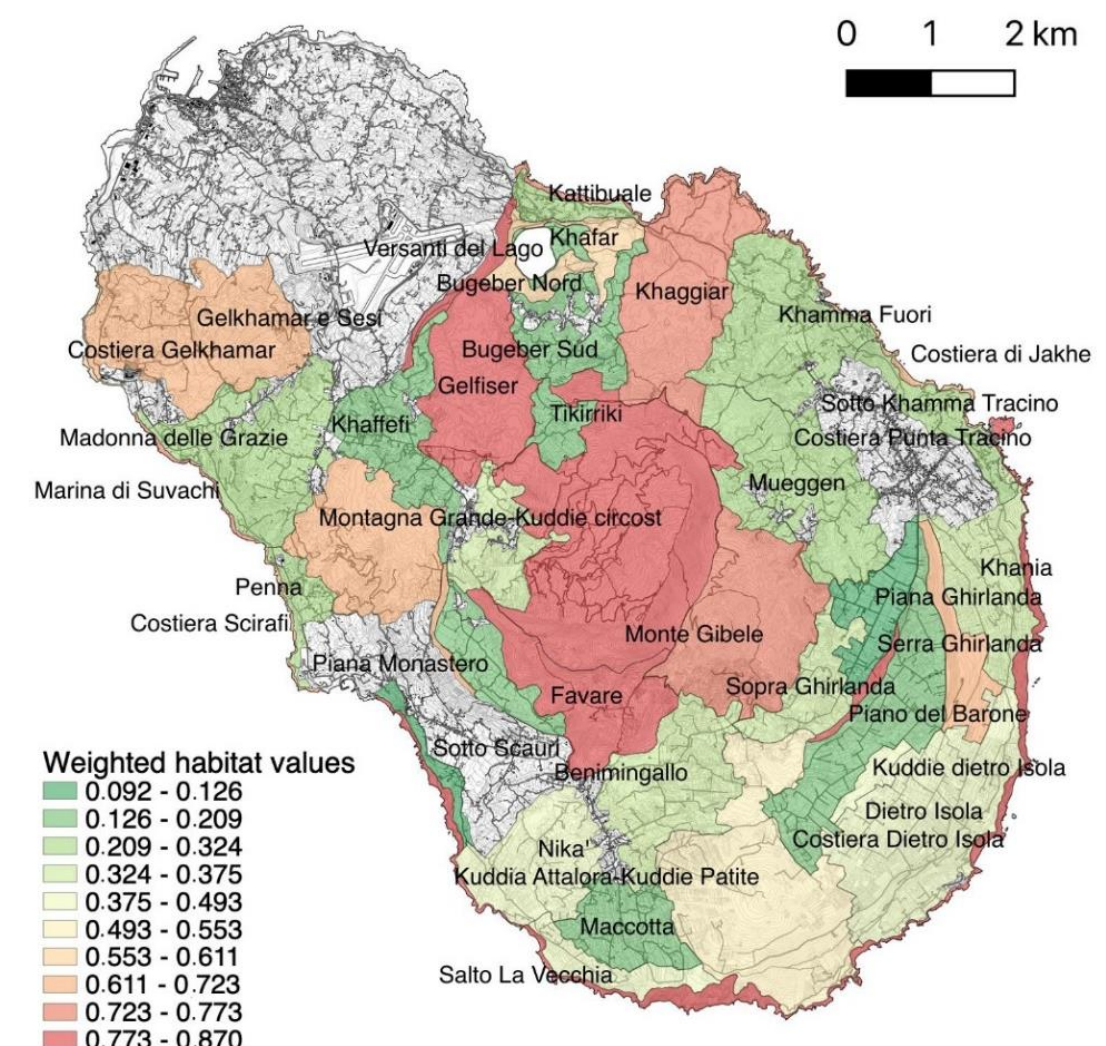

Figure 9. Weighted habitat values within Landscape Sub-systems. (Source: Authors' elaboration). 
The highest quality is found in the mountain, coastal, volcanic edge and lava flow Subsystems. In the mid-high classes other mountain and volcanic subsystems can be found, while the middle classes show a transition between natural and human-made areas. In particular, abandoned agricultural Subsystems are in the mid-low classes, while most active agricultural areas are in the lowest classes.

After these evaluations, modifying the zoning of the Pantelleria National Park introduced by the DPR 28.07.2016, a new division of 4 zones was provided for the Park Plan (Figure 10):

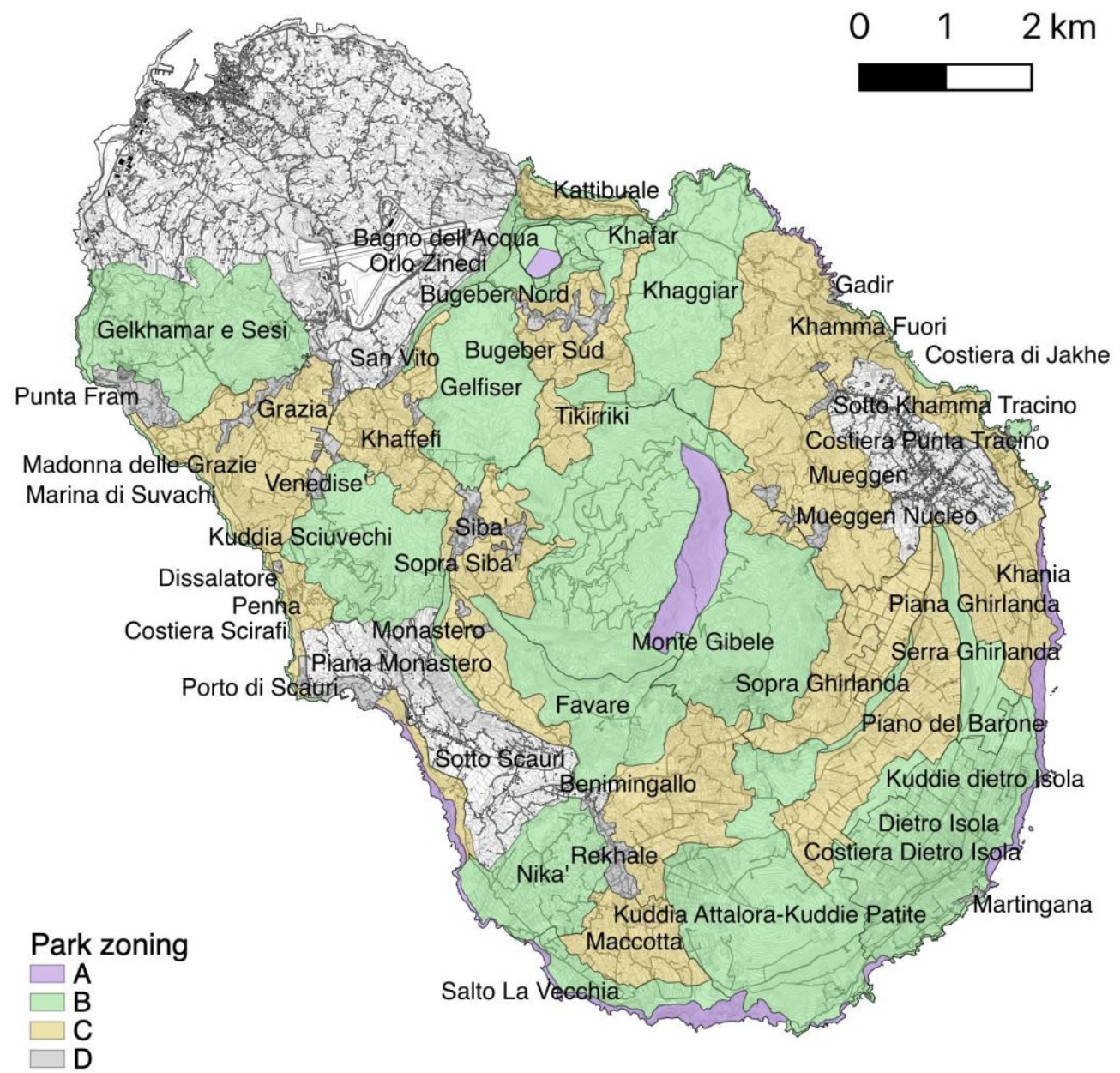

Figure 10. Park zoning proposal. (Source: Authors' elaboration).

Zone A, featuring full protection (Riserva Integrale), contains those Subsystems with the highest natural quality and integrity, that host the most relevant biodiversity: the most preserved sections of the coastal Subsystems (Falesie e Coste Marine); the southern section of the lake (Bagno dell'Acqua); the section of one of the mountain Subsystems hosting an extremely important holm oak wood (Montagna Grande e Kuddie Circostanti).

Zone B, with targeted protection (Tutela Orientata), hosts Systems and Subsystems characterized by high levels of naturality and integrity: the coastal Subsystems (Falesie e Coste Marine) not included in Zone A, often featuring beaches and access to the sea; the lake and surrounding areas (Lago Specchio di Venere), excluding the section in zone A; the mountain Subsystems (Grandi Rilievi), with the exclusion of the section in zone A; the hills Subsystems (Kuddie Maggiori); the lava flow Subsystems (Colate Laviche Fratturate); the caldera edges Subsystems (Orli Calderici); three former cultivated Subsystems with higher environmental quality (Nikà, Salto La Vecchia, Dietro Isola).

Zone $\mathrm{C}$, featuring a general protection (Protezione), hosts those areas containing the typical Pantelleria rural landscape, alternating cultivated and abandoned areas: the 
remaining cultivated and former cultivated Subsystems (Versanti dei Coltivi e degli Ex Coltivi); the cultivated plains Subsystems (Pianure Coltivate).

Zone D, aimed at social and economic promotion (Promozione Economica e Sociale), containing all settlements (Sistema Insediativo).

\section{Discussion}

In accordance with the Framework Law on Protected Areas, the Pantelleria National Park aims to combine its' environmental mission (the management of ancient woods on the volcanic hills, the conservation of fragile habitats and the strengthening of the role of Pantelleria as a stepping stone for bird migrations) with a social mission addressing local development issues [79].

At a close inspection, possible conflicts may arise in the reassertion of agricultural activities, with potential to bring positive effect on both local economies and landscapes, though with possible loss of natural habitats strictly protected by the Habitat Directive. In fact, the National Park Authority is in charge of balancing relentless encroachments between Nature and Culture whose interplay is determined both by exogenous unplanned agents as well as social and institutional conflicts [80].

Looking ahead, solidarity between the two realms standing for intrinsic sustainability of centuries old assets should be reaffirmed through integrated planning and management tools [81]. Specifically, the work attempted to compare and combine ex-ante the rationales linked to Nature and Culture as to avoid further conflict in subsequent implementation of planning tools. As per this aim, the vision provided for the Park considers a reduction of the areas under integral protection, considering that the majority of areas with habitats of particular quality, for geomorphological reasons, already had largely irrelevant pressures and threats, while the particularly sensitive areas (such as the lake) were included in this first category (i.e., Zone A). Moreover, it was preferred to expand the areas of oriented protection (Zone $\mathrm{B}$ ) and to introduce a third area of general protection (Zone $\mathrm{C}$ ) coinciding substantially with the landscape system of current and formerly cultivated fields typical of the historical rural landscape (also coinciding with the areas of the National Register of Historical Rural Landscapes). Furthermore, a new delimitation and categorization of the settlements (villages and hamlets) was carried out to minimize the urban dispersion (Zone D).

The main axes of the Park vision can be summarized as follows: a Park (i) careful to the environmental resources integrity and their potential conscious use; (ii) able to flexibly manage the dialectic between natural environments and rural landscape, understood not only as a perceptive value but also as a productive reality; (iii) attentive to the quality of building transformations, notably rural heritage.

The establishment of the Pantelleria National Park represents an innovation in the system of Italian and Mediterranean protected areas due to its peculiar condition as an island, in the light of the ambitious goals of the new European Biodiversity Strategy 2030, an overall and long-term plan to protect nature and reverse ecosystem degradation targeting at least $30 \%$ of total land and sea surface [82]. Small islands are pivotal for studying the environmental dynamics in Italy and the Mediterranean as evidenced by the "Progetto Piccole Isole" (Small Islands Project) led by ISPRA-Italian National Institute for Environmental Protection and Research developing monitoring experiences related to the effects of climate change through the study of migratory birds [83].

Despite being recognized as laboratories of sustainable development, small islands are rarely protected at land level both in Italy and the Mediterranean. The Pantelleria National Park, holding a substantial protected surface on the mainland threatened by significant pressures, provides valuable insights making it possible to infer provisions for the whole Mediterranean, in terms of climate change effects management (adaptation and mitigation) and of sustainable measures to address human activities (energy supply, waste cycle management, water cycle, agriculture, sustainable tourism, etc.). 
A possible step forward, in the light of the Mission 2-Ecological Transition within the National Recovery and Resilience Plan (NRRP), could be met in the investment "Digitization of National Parks" supporting the implementation of standardized and digitized procedures in three strategic areas: nature conservation, visitor services, administrative simplification. This budget heading is reserved to better perform the management of all 24 Italian National Parks and 31 Marine Protected Areas. Since Landscape has not been considered, its inclusion as an additional layer could lead to a proper understanding of perceptive and cultural values in protected areas [84].

According to the outcomes of the research and considering the guidelines of the Law 394/91, the following management rules have been provided:

- To control urbanized areas with the aim of maintaining the functional and perceptive relationship with the surrounding countryside;

- To protect the fertility and permeability of the soil, authorising the extension of existing buildings in rural areas only in case of activities linked to agriculture production and transformation;

- To protect the elements of the built heritage of historical-architectural value (as explained in Table 5) by providing specific directions for their restoration;

- To reuse abandoned dammusi for purposes linked to the Park's reception facilities;

- To support entrepreneurs in transition to sustainable agricultural practices (e.g., research and assistance aimed at eliminating the use of pesticides not allowed in organic farming).

Finally, the landscape approach carried out in this work-both in methodological terms and for territorial governance purposes-is applicable to other Italian National Parks due to their similar morphological, environmental and cultural conditions (in particular the following National Parks: Cinque Terre, Cilento, Vallo di Diano and Alburni, Asinara and Tuscan Archipelago), and generally to further protected areas (existing or future) with similar climatic, environmental and social characteristics in the Mediterranean Basin (i.e., Spain, Greece, Turkey, Croatia).

\section{Conclusions}

The establishment of Landscape as a key for management measures addressing nature conservation is widely acknowledged in the case of the Mediterranean region that "runs from the first olive tree one encounters when coming from the north to the first palm groves that appear with the desert" [85].

In turn, evidence stemming from thorough investigation carried out on Natura 2000 sites (so-called 'active interventions') allows for a two-way relationship between natura naturans and natura naturata (that is, ultimately, Culture), with synergistic integrations between human activities and conservation of species and habitats [86].

Accordingly, the transdisciplinary reading of Landscape Systems (and Subsystems), and the proposed zoning for Pantelleria Park may provide a common ground to support decision making and management in homogenous areas where Nature and Culture interweave and are liable to accommodate synergistic development paths.

Pantelleria was for a long time set apart from trade flows and bears witness of strong influence of human subsistence strategies over the dynamics related to species and habitats. Such hybridization between human activity and wild nature, while accounting for high biodiversity, is taken into consideration as an inherent value by scientific and local communities, and as such deserves further interdisciplinary insights. The governance of these dynamics, notably the definition of 'mobile boundaries' in the possible relaunch of traditional agriculture, should naturally be built through a dialogue between institutions at different levels and local communities.

Author Contributions: Conceptualization, R.D.A. and A.L.P.; formal analysis, R.D.A., L.B., G.D.P., A.F. and A.L.P.; funding acquisition, G.D.P.; investigation, R.D.A., L.B., G.D.P., A.F. and A.L.P.; methodology, G.D.P., A.F. and A.L.P.; software, L.B.; supervision, A.F. and A.L.P.; visualization, L.B. 
and R.D.A.; writing—original draft, R.D.A., L.B., G.D.P., A.F. and A.L.P.; writing-review and editing, R.D.A., L.B. and A.L.P. All authors have read and agreed to the published version of the manuscript.

Funding: This research was funded by the Pantelleria National Park Authority through the project "Analysis and guidelines for the protection and enhancement of rural landscapes of Pantelleria Island: towards the Park Plan" entrusted to the Department of Architecture, Roma Tre University and Department of Agricultural, Food and Forest Sciences, University of Palermo.

Institutional Review Board Statement: Not applicable.

Informed Consent Statement: Not applicable.

Data Availability Statement: Not Applicable.

Acknowledgments: The Authors are grateful to the "Isola di Pantelleria" National Park Authority, Salvatore Gino Gabriele and Sonia Anelli for the opportunity granted to the Department of Architecture of Roma Tre University to carry out the research. Our appreciation is also addressed to the Officers of the Park Authority (Gaspare Inglese, Carmine Vitale, Nanni Siragusa, Andrea Bidittu) for the materials made available. We are also grateful to all the other researchers who worked in the multidisciplinary team: Laura Calcagnini, Paolo Desideri, Giovanni Formica, Luigi Franciosini, Tommaso La Mantia, Donato Salvatore La Mela Veca, Antonio Motisi, Elisabetta Pallottino, Francesca Romana Stabile. Furthermore, the Authors would like to thank Paolo Pigliacelli, Head of the Projects Department of Federparchi Europarc Italy, for the insights provided for some theoretical passages in the conceptualization of this article. The Authors would like to thank the reviewers for their careful and constructive comments.

Conflicts of Interest: The authors declare no conflict of interest.

\section{References}

1. Vogiatzakis, I.N.; Pungetti, G.; Mannion, A. (Eds.) Mediterranean Island Landscapes: Natural and Cultural Approaches; Landscape Series, 9; Springer Publishing: Dordrecht, The Netherlands, 2008; pp. 101-114.

2. Grove, A.T.; Rackham, O. The Nature of Mediterranean Europe: An. Ecological History; Yale University Press: New Haven, CT, USA, 2001.

3. Brown, J.; Mitchell, N.; Beresford, M. (Eds.) Protected landscapes: A conservation approach that links nature, culture and community. In The Protected Landscape Approach. Linking Nature, Culture and Community; IUCN: Gland, Switzerland, 2005; pp. 3-18.

4. Palazzo, A.L.; Barbieri, L.; D'Ascanio, R.; De Pasquale, G.; Filpa, A. Natura e cultura: Conflitto o cooperazione? Riflessioni sul Parco Nazionale di Pantelleria. Urban. Inf. 2021, 295, 90-91.

5. Italian Ministry for Ecological Transition. Law 394/91-Framework Law on Protected Areas; Italian Ministry for Ecological Transition: Rome, Italy, 1991.

6. Hawkes, J. The Fourth Pillar of Sustainability. Culture's Essential Role in Public Planning; Common Ground Publishing Pty Ltd.: Melbourne, Australia, 2001.

7. Burgi, M.; Hersperger, A.M.; Schneeberger, N. Driving forces of landscape change-Current and new directions. Landsc. Ecol. 2004, 19, 857-868. [CrossRef]

8. Bürgi, M.; Bieling, C.; Von Hackwitz, K.; Kizos, T.; Lieskovský, J.; Martín, M.G.; Printsmann, A. Processes and driving forces in changing cultural landscapes across Europe. Landsc. Ecol. 2017, 32, 2097-2112. [CrossRef]

9. Council of Europe. The Declaration of Amsterdam: Congress on the European Architectural Heritage; Council of Europe: Strasbourg, France, 1975.

10. Quatrémère de Quincy, A.C. Lettres sur le Préjudice Qu'occasionneroient aux Arts et à la Science le Déplacement des Monuments de l'Art en Italie, le Démembrement de ses Ecoles, et la Spoliation de ses Collections; Edition Macula: Paris, France, 1989; (Paris, 1796).

11. UNESCO. Convention Concerning the Protection of the World Cultural and Natural Heritage; UNESCO: Paris, France, 1972.

12. UNESCO. Operational Guidelines for the Implementation of the World Heritage Convention; UNESCO: Paris, France, 2015.

13. UNESCO. Convention for the Safeguarding of Intangible Cultural Heritage, Paris, 2003. Available online: http:/ / www.unesco. org/culture/ich/en/convention (accessed on 12 September 2021).

14. Phillips, A. Management Guidelines for IUCN Category V Protected Areas: Protected Landscapes/Seascapes; IUCN: Gland, Switzerland; Cambridge, UK, 2002.

15. Dudley, N. (Ed.) Guidelines for Applying Protected Area Management Categories; IUCN: Gland, Switzerland; Cambridge, UK, 2008; Available online: https://www.iucn.org/sites/dev/files/import/downloads/iucn_assignment_1.pdf (accessed on 28 October 2021).

16. Mitchell, N.; Buggey, S. Protected Landscapes and Cultural Landscapes: Taking Advantage of Diverse Approaches. George Wright Forum 2000, 17, 35-46.

17. Phillips, A. Cultural Landscapes: IUCN's Changing Vision of Protected Areas. In UNESCO. Cultural Landscapes: The Challenges of Conservation; World Heritage Papers No. 7.; UNESCO World Heritage Centre: Paris, France, 2003; pp. 40-49. 
18. Phillips, A. Landscape as a meeting ground: Category V Protected Lanscapes/Seascapes and World Heritage Cultural Landscapes. In The Protected Landscape Approach: Linking Nature, Culture and Community; Brown, J., Mitchell, N., Beresford, M., Eds.; IUCN: Cambridge, UK, 2005; pp. 19-35.

19. Palazzo, A.L.; Rizzo, B.M. Paesaggio, Storia e Partecipazione. La Convenzione Europea a San Marino; Officina: Rome, Italy, 2007; pp. 11-13.

20. Council of Europe. European Landscape Convention; Council of Europe: Florence, Italy, 2000.

21. CBD (Convention on Biological Diversity). Strategic Plan for Biodiversity 2011-2020, Including Aichi Biodiversity Targets, 2011. Available online: https://www.cbd.int/sp/ (accessed on 28 October 2021).

22. Council of Europe. European Cultural Convention; Council of Europe: Paris, France, 1954.

23. Council of Europe. Faro Convention, STCE n. 199/2006. Available online: http://www.coe.int/web/culture-and-heritage/faroconvention (accessed on 10 September 2021).

24. Council of Europe. Convention on the Value of Cultural Heritage for Society; Council of Europe Treaty Series-No. 199, Faro; Council of Europe: Paris, France, 2005.

25. Gambi, L. Una Geografia per la Storia; Einaudi: Torino, Italy, 1973.

26. Rombai, L. Geografia Storica dell'Italia. Ambienti, Territori, Paesaggi; Le Monnier: Milano, Italy, 2015.

27. Coppa, M. Studio Preliminare Piano Territoriale Paesistico della Costiera Amalfitana; Editoriale Umbra SAS: Foligno, Italy, 1972.

28. Gambino, R. Piani paesistici. Uno sguardo d'insieme. Urbanistica 1988, 60, 6-23.

29. Gambino, R. Il paesaggio edificato. Piani paesistici e prospettive di recupero. Recuperare 1989, 40, $33-45$.

30. Gambino, R. Conservare Innovare. Paesaggio Ambiente e Territorio; Einaudi: Torino, Italy, 1997.

31. Gambino, R.; Peano, A. Nature Policies and Landscape Policies. Towards an Alliance; Springer: Dordrecht, The Netherlands, 2005.

32. Gambino, R.; Sargolini, M. (Eds.) Mountain Landscapes. A Decision Support System for the Accessibility; List: Trento, Italy, 2013.

33. Morandi, F.; Niccolini, F.; Sargolini, M. Parks and Territory. New Perspectives in Planning and Organization; List: Trento, Italy, 2012.

34. Italian Ministry of Culture. Legislative Decree No. 42 of 22 January 2004, Code of the Cultural and Landscape Heritage; Italian Ministry of Culture: Rome, Italy, 2004.

35. Calcara, P. Descrizione dell'isola di Pantelleria. Atti Accad. Sci. E Lett. 1853, 2, 44.

36. Orsi, P. Pantelleria: Risultati di una Missione Archeologica; Tipografia della R. Accademia dei Lincei: Roma, Italy, 1899.

37. Tommasini, G. Pantelleria. L'Universo Riv. Dell'istituto Geogr. Mil. 1965, 4, 35-48.

38. Bonasera, F. L'isola di Pantelleria; Patron: Bologna, Italy, 1965.

39. Barbera, G.; Cullotta, S.; Rossi-Doria, I.; Rühl, J.; Rossi-Doria, B. I Paesaggi a Terrazze in Sicilia: Metodologie Per L'Analisi, la Tutela e la Valorizzazione; Collana di Studi e Ricerche dell'Agenzia Regionale Protezione Ambiente: Palermo, Italy, 2010.

40. Barbera, G.; La Mantia, T.; Quatrini, P. Il sistema agricolo delle terrazze dell'Isola di Pantelleria. In Proceedings of the Atti del IV International Conference on Dry Stone Construction, Palma de Mallorca, Spain, 28-30 September 1994; pp. $235-245$.

41. Barbera, G.; Rühl, J. Umanesimo della Pietra. I Terrazzamenti delle Isole del Canale di Sicilia: Tra Calcare e Vulcanico. In Paesaggi Rurali italiani-Tra Natura ed Agricoltura; Ministero dell'Ambiente della Tutela del Territorio e del Mare: Roma, Italy, 2009; pp. 178-181.

42. De Pasquale, G. Paesaggi terrazzati dell'Italia meridionale: Un'analisi comparativa tra passato, presente e future. Ann. Ser. Hist. Sociol. 2018, 28, 709-724.

43. Amico, V. Lexicon Topographicum Siculum; (Translated by G. Di Marzo); Tip. Morvillo: Palermo, Italy, 1855 ; Volume 1.

44. Cattani, M.; Tusa, S. Paesaggio agro-Pastorale e spazio rituale nell'età del Bronzo a Pantelleria. In Proceedings of the XLI Riunione Scientifica, San Cipirello, Italy, 16-19 November 2006.

45. D'aietti, A. Il Libro Dell'isola di Pantelleria; Trevi Editore: Milano, Italy, 1978.

46. D'aietti, G. Pantelleria. L'isola di Terra; Il Pettirosso: Mazara del Vallo, Italy, 2015.

47. Calcara, P. Breve cenno sulla geognosia ed agricoltura dell'Isola di Pantelleria. G. Della Comm. Di Agric. E Pastor. Sicil. 1854, 3-4.

48. Barbera, G.; La Mantia, T. Sistema agricolo e paesaggio nell'isola di Pantelleria. Italus Hortus 1988, 1, $23-28$.

49. Barbera, G.; Sganzerla, A. Pantelleria di Luce e Di Vento, di Pietra e di Fiori; Rizzoli: Milano, Italy, 2016.

50. Brandi, C. Sicilia Mia; Sellerio: Palermo, Italy, 1989.

51. Di Lorenzo, R.; Sottile, I. Aspetti e problemi della viticoltura dell'isola di Pantelleria. Agricoltura 1990, $209,94-97$.

52. Giuntoli, G. Evoluzione del dammuso nel paesaggio antropizzato. In Relazione Allegata al Piano Territoriale Paesistico; Pantelleria, Italy, 1997.

53. Brignone, F. I Giardini Dell'isola di Pantelleria; Litotipografia Nuova Stampa: Trapani, Italy, 2012.

54. Brignone, F. U Jardinu; Dario Flaccovio Edtore: Palermo, Italy, 2001.

55. Barbera, G.; Chieco, C.; Georgiadis, T.; Motisi, A.; Rossi, F. The jardinu of Pantelleria as a paradigm of resource efficient horticulture in the built-up environment. Acta Hortic 2018, 1215, 351-356. [CrossRef]

56. De Pasquale, G.; Savelli, S. Intangible Heritage between Landscape Protection and Territory Development. A Plan for the Island of Pantelleria. In Proceedings of the XVIII International Forum, World Heritage and Contamination; Gangemi Editor International Publishing: Roma, Italy, 2020; pp. 760-765.

57. De Pasquale, G. Il Paesaggio Rurale Tradizionale Dell'Isola di Pantelleria, Collana; I Quaderni del Parco: Pantelleria, Italy, 2020; Volume 1. 
58. De Pasquale, G.; Ganciu, A.; Lotta, F.; Savelli, S. Il Paesaggio Della Pietra a Secco Dell'Isola di Pantelleria, Dossier di Candidatura al Registro Nazionale dei Paesaggi Rurali Storici, 2018. Available online: https://www.reterurale.it/flex/cm/pages/ServeBLOB. $\mathrm{php} / \mathrm{L} / \mathrm{IT} /$ IDPagina/17423 (accessed on 25 September 2021).

59. Desplanques, H. Il paesaggio rurale della cultura promiscua in Italia. Riv. Geogr. Ital. 1959, $29-64$.

60. Bevilacqua, P. Tra Natura e Storia. Ambiente, Economie, Risorse in Italia; Donzelli: Roma, Italy, 2000.

61. Agnoletti, M. (Ed.) Paesaggi Rurali Storici: Per un Catalogo Nazionale; Laterza: Roma, Italy, 2010.

62. Agnoletti, M.; Neri Serneri, S. (Eds.) The Basic Environmental History; Springer International Publishing: Cham, Switzerland, 2014.

63. Phillips, A. The nature of cultural landscapes-A nature conservation perspective. Landsc. Res. 1998, 23, 21-38. [CrossRef]

64. Phillips, A. Turning Ideas on Their Head: The New Paradigm of Protected Areas. Georg. Wright Forum 2006, 20, 8-32.

65. Ervin, J.; Mulongoy, K.J.; Lawrence, K.; Game, E.; Sheppard, D.; Bridgewater, P.; Bennett, G.; Gidda, S.B.; Bos, P. Making Protected Areas Relevant: A guide to integrating protected areas into wider landscapes, seascapes and sectoral plans and strategies. $C B D$ Tech. Ser. 2010, 44, 94 .

66. Dudley, N.; Stolton, S. Protected Landscapes and Wild Biodiversity, Volume 3. In The Values of Protected Landscapes and Seascapes Series; IUCN: Gland, Switzerland, 2012; p. 104.

67. Sereni, E. Storia del Paesaggio Agrario Italiano; Laterza: Bari, Italy, 1961.

68. Komnitsas, K.A.; Doula, M.K. Framework to improve sustainability of agriculture in small islands: The case of Pistacia vera L. cultivation in Aegina, Greece. Environ. Forensics 2017, 18, 214-225. [CrossRef]

69. De Pasquale, G. Tutelare le pratiche agricole eroiche. Il ruolo del paesaggio e del Progetto. In Paesaggi terrazzati: Scelte per il Futuro/Terraced Landscapes: Choosing the Future; Alberti, F., Dal Pozzo, A., Murtas, D., Salas, M.A., Tillman, T., Eds.; Regione del Veneto: Venezia, Italy, 2018; pp. 493-498.

70. Carl, T.; Richter, M. Geoecological and morphological processes on abandoned vine-Terraces in the Cinque Terre (Liguria). Geoökodynamik 1989, 10, 125-158.

71. Rühl, J. Vascular Plant Diversity in Abandoned Vine and Caper Cultures of Pantelleria Island (Sicily) and Conclusions for Landscape Conservation. Master's Thesis, Ernst Moritz Arndt-Universitaet, Greifswald, Germany, 2003.

72. Rühl, J. Analisi dei processi di rinaturalizzazione nei vigneti e cappereti abbandonati del paesaggio terrazzato di Pantelleria (Canale di Sicilia). Nat. Sicil. 2004, 4, 3-4.

73. Baratta, B.; Barbera, G. La forma di allevamento nell'olivicoltura di Pantelleria. Frutticoltura 1981, 12, 43-45.

74. Barbera, G. Il Cappero; Edagricole: Bologna, Italy, 1993.

75. Barbera, G.; Di Lorenzo, R. La coltura specializzata del cappero nell'isola di Pantelleria. Inf. Agrar. 1982, 32, $22113-22117$.

76. La Mantia, T. Foreste siciliane e rinaturalizzazione dell'isola di Pantelleria. Arpa View 2007, 13, 11-12.

77. Brullo, S.; Di Martino, A.; Marcenò, C. La Vegetazione di Pantelleria; Istituto Botanico dell’Università di Catania: Catania, Italy, 1977.

78. Gianguzzi, L. Vegetazione e bioclimatologia dell'isola di Pantelleria (Canale di Sicilia). Braun-Blanquetia 1999, 22, 1-70.

79. Marsden, T.; Banks, J.; Bristonw, G. The social management of rural nature: Understanding agrarian based rural development. Environ Plan. A Econ. Space 2002, 34, 809-825. [CrossRef]

80. Palazzo, A.L.; D’Ascanio, R.; Zaccardi, E. La Metafora Verde. Economie ed Ecologie di un'Area Interna del Lazio; Magaudda, S., Muccitelli, S., Palazzo, A.L., Eds.; iQuaderni di U3; 2020; Volume 24, pp. 15-25, in press.

81. De Pasquale, G.; Barbieri, L.; Calcagnini, L.; D’Ascanio, R.; Desideri, P.; Filpa, A.; Formica, G.; Franciosini, L.; La Mantia, T.; La Mela Veca, D.S.; et al. Indirizzi di Tutela e Valorizzazione del Paesaggio Rurale dell'Isola di Pantelleria Propedeutico alla Redazione del Piano del Parco. Relazione Generale; Documento Consegnato Presso l'Ente Parco Nazionale Isola di Pantelleria: Pantelleria, Italy, 2021.

82. EC. Communication from the Commission to the European Parliament, the Council, the European Economic and Social Committee and the Committee of the Regions. In EU Biodiversity Strategy for 2030. Bringing Nature Back into Our Lives; European Commission: Bruxelles, Belgium, 2020.

83. Italian National Institute for Environmental Protection and Research (ISPRA) Progetto Piccole Isole. Available online: https: //www.isprambiente.gov.it/it/archive/notizie-e-novita-normative/notizie-ispra/anno-2012/progetto-piccole-isole (accessed on 15 September 2021).

84. Italian Government. The National Recovery and Resilience Plan (NRRP). 2021. Available online: https://www.governo.it/sites/ governo.it/files/PNRR.pdf (accessed on 15 September 2021).

85. Braudel, F. La Méditerranée. Espace et Histoire; Flammarion: Paris, France, 1988.

86. Ministry for the Ecological Transition, Manuale per la Gestione dei siti Natura 2000. Available online: https: / www.mite.gov.it/ sites/default/files/archivio/allegati/rete_natura_2000/manuale_gestione_siti_natura2000.pdf (accessed on 26 September 2021). 